\section{ECONOMICS

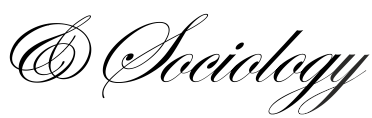

Adam P. Balcerzak,

Nicolaus Copernicus University,

Toruń, Poland,

E-mail:adam.balcervak@umk.pl

Michał Bernard Pietrzak, Nicolaus Copernicus University,

Torun, Poland,

E-mail:michal.pietrzak@umk.pl

Received: June, 2016

1st Revision: October, 2016

Accepted: November, 2016

DOI: $10.14254 / 2071-$

789X.2016/9-4/4
Balcerzak, A. P., Pietrzak, M. B. (2016), Quality of Institutions for Knowledgebased Economy within New Institutional Economics Framework. Multiple Criteria Decision Analysis for European Countries in the Years 2000-2013, Economics and Sociology, Vol. 9, No 4, pp. 66-81. DOI: 10.14254/2071-

789X.2016/9-4/4

\title{
QUALITY OF INSTITUTIONS FOR KNOWLEDGE-BASED ECONOMY WITHIN NEW INSTITUTIONAL ECONOMICS FRAMEWORK. MULTIPLE CRITERIA DECISION ANALYSIS FOR EUROPEAN COUNTRIES IN THE YEARS 2000-2013
}

\begin{abstract}
The article concentrates on the problem of quality of institutions in the European Union countries in the context of their compatibility with the global knowledge-based economy. The main objective of the article is to evaluate the progress obtained in that field by New Member States of the European Union in the years 2000-2013. The empirical research is based on the following hypothesis: the integration process of Central European countries with the European Union has influenced the acceleration of changes leading to improvement in the quality of their institutional systems in the context of global knowledge-based economy. The first part of the paper presents the most important determinants of the ability of a country to utilize the potential of the knowledge-based economy. This analysis is conducted on the basis of institutional economics specifically transaction cost theory. In the empirical part multiple criteria decision analysis methodology (MCDA) (the modified TOPSIS method) is applied. Data from Fraser Institute data base for Economic Freedom of the World Report has been used. The empirical research is the source of significant arguments in favor of the hypothesis of the paper.
\end{abstract}

JEL Classification: C38,

Keywords: institutional economics, quality of institutions, D02, O38 transaction cost theory, global knowledge-based economy, multiple criteria decision analysis (MCDA), TOPSIS, EU.

\section{Introduction}

Last decades have brought many significant changes in the structure of the world economy which influence the main determinants of economic processes. First of all, among the new phenomena forming contemporary economy one can point the fundamental technological change leading to forming global knowledge-based economy (see: Pohulak- 
Żołędowska, 2016; Kondratiuk-Nierodzińska, 2016; Kowalska, 2016). The different economic results obtained by highly developed countries in utilizing the potential of globalization and technological changes for the last two decades (see: Scarpeta and Tressel, 2004; Balcerzak and Pietrzak, 2016a) have proved that intuitional factors can become obstacle for growth not only in the case of underdeveloped economies (Rodrik, 2007), but quality of institutions significantly influences welfare also in the case of highly developed economies (Balcerzak and Pietrzak, 2016b; Lizińska et al., 2016). This factor creates a scientific demand for international comparative research in the field. In this context, in spite of many methodological dilemmas (see: Buchanan et al., 2014) the institutional economists have taken serious effort to develop the methodology for empirical formalization and quantification of multidimensional qualitative institutional factors, which is necessary for making international comparisons of countries (see: Gwartney et al., 2015; Schwab and Sala-i-Martín, 2015; Jantoń-Drozdowska and Majewska, 2016; Kordalska and Olczyk, 2016; Doing Business, 2016, Miller et al., 2016). The research presented in this paper should be considered as an input to this empirical effort. The empirical research concerns quality of institutions for knowledge-based economy in the case of the EU countries. It is done for the period 20002013 and is based on the data from Fraser Institute data base for Economic Freedom of the World Report. It is continuation of previous quantitative research of the authors concentrating on international comparative research on quality of institutions in developed countries (Balcerzak, 2009, 2015a; Balcerzak and Pietrzak, 2016c, 2016d; Pietrzak and Balcerzak, 2016a).

The main aim of the article is to evaluate the progress obtained by so called new member states of the European Union in the process of regulation reforms and improving quality of their institutions for global knowledge-based economy. For this purpose the research is based on the following thesis: The integration process of Central European countries with the European Union has influenced the acceleration of changes leading to improvement in the quality of their institutional systems in the context of global knowledgebased economy. The research is conducted for the years 2000-2013. As a result, it covers the time of significant formal institutional changes that had to be implemented by Central European countries before the accretion to the EU and the first years after completing formal integration.

Additionally, the empirical analysis can be useful in pointing the group of countries that can be considered as leaders and be the source of good practices in the effort to form effective institutional order. This aim is significant from the perspective of creating recommendations for future regulation modifications or policy-making and, for example, forming national strategies that can lead to getting closer to obtaining some aims formed in Europe 2020 strategy (Balcerzak, 2015b).

The article completes and improves existing studies by:

1. Proposing methodology of measuring quality of institutions for knowledge-based economy that is based on the new institutional economy approach, in that case mostly using transaction cost theory framework. Most of the existing commonly used ratings such as Index of Economic Freedom prepared by Fraser Institute, Doing Business Rapport of the World Bank or Global Competitiveness Rapport include not only institutional factors, but also elements attributed to current economic policy as it is in the case of the first two mentioned ratings, or are concentrated on a specific factor as the last one.

2. Application of multiple criteria decision analysis (MCDA) methodology - specifically modified TOPSIS method - to the problem of measurement of quality of institutional systems for global knowledge-based economy. This can be important from the perspective of development of quantitative tools that can be applied in new institutional economy framework. Providing and testing new quantitative approaches for estimation of multivariate 
qualitative factors can be considered as the condition of development and improvement of institutional theory.

\section{The Main Determinants of Quality of Institutions for Global Knowledge-based Economy}

The experiences of the last three decades of highly developed countries has proved the significant role of institutional factors in determining the economic success in a quickly changing environment. That has been seen especially in the case of unequal distribution of benefits of globalisation and technological change utilized by countries that are on a similarly high level of development that can be characterized with quite similar availability of so called conventional economic resources, such as financial and technical capital, human capital with high qualifications, which together lead to highly enough labour ratio. In spite of the fact that these countries fulfilled most of conditions that should place them in one convergence club, even in the case of highly developed countries last decades have shown rather a divergence of their total factor productivity, which in the end must lead to significant differences in the well-being of societies (Gust and Marquez, 2000; Denis et al., 2005).

The divergence of productivity growth in the case of highly developed countries was the impulse for starting broad international research. The first hypothesis was concentrated on the role of technological change, especially the growing importance of information technology in dynamic global knowledge-based economy (Bassanini et al., 2000; Balcerzak, 2015; Balcerzak and Pietrzak, 2016c). However, the OECD research program concentrating on the productivity changes in highly developed countries showed that traditionally defined resources, such as technology; in that case the utilization of telecommunication technologies, should be treated only as one of the broader vector of potential reasons for productivity divergence. The research program proved that the institutional factors should be treated as the most important determinants of high productivity growth in some highly developed countries. The multilevel research showed that especially the quality of national institutional systems in the context of global knowledge-based economy as a new technological paradigm is the most important determinant of productivity growth (Bassanini et al., 2001). These conclusions were also confirmed econometrically with application of dynamic panel analysis of the influence of quality of intuitions on total factor productivity growth in European Union countries in the years 2000-2010 (Pietrzak and Balcerzak, 2016b).

Currently, there are many definitions of knowledge based-economy. However, most of researchers agree that modern developed economy with high growth potential should be considered as a global entrepreneurial and flexible, knowledge-based economy where the drivers of growth depend on the extent to which knowledge, technology, and innovation are embedded in products and services (Atkinson and Correa, 2007; OECD, 1996). As a result among the most significant institutional factors that are necessary to utilize the potential of global knowledge-based economy defined in that way, one could find the effectiveness of structural reforms that resulted in lower level of transaction costs in the economy, increased the competitive intensity on the national markets and supported the level of national entrepreneurship (Bassanini et al., 2001).

In spite of the fact that the concept of quality of institutional system is currently considered as the core of institutional economics, it is still very difficult to operationalize and define. The literature in the field can vary from the historical analysis of influence of different institutions on the long-term development (North, 1994a, 1994b), the macro perspective on the role of bureaucratic quality, the rule of law and property rights, the role of economy openness or the level of corruption (see more: Islam and Montenegro, 2002). However, the whole theoretical and empirical perspective of that paper concentrates on the quality of 
institutions that significantly influence the chances of countries to utilize the potential of global knowledge-based economy. The definition of quality itself is based on the economic role of low level of transaction costs in complex economies and is rooted in the new institutional economics, especially in theory of transaction costs (see Williamson, 1985; North, 1991, 1993).

Based on the research concerning highly developed economies one can point out a few most significant segments of national institutional systems that determine productivity growth, thus long term well-being of societies, in the reality of the global knowledge-based economy (Balcerzak, 2015; Balcerzak and Pietrzak, 2016c). The crucial role is given to the system of regulations that influence the incentives for entrepreneurship and the effectiveness of financial systems institutions that together create the framework for high supply of enterprises with high growth potential (Felipe and Oto, 2015; Zineker et al., 2013; Zinecker and Bolf, 2015; Meluzín and Zinecker, 2016; Fałdziński et al., 2016). These enterprises are responsible for providing new technological and organizational solutions giving the base for productivity growth. The effectiveness of financial markets is here as important as entrepreneurship itself due to the fact that it supports quick reallocation of capital and other economic resources from the low growth potential to high growth potential enterprises (OECD, 2001).

The next crucial segments of national institutional systems make the formal and informal rules and regulations that influence the level of transaction costs, and thus they influence the effectiveness of market mechanism. The last, but definitely not least, are the micro and macroeconomic regulations responsible for the competitive intensity of internal markets and external international competitiveness of economy. The relatively low level of transaction cost with high competitive pressure make the institutional mixture that increase the speed of innovation diffusion, which when reaching the critical mass leads to higher level of productivity growth (Balcerzak and Pietrzak, 2016c). Thus, the level of transaction costs and competitive intensity goes usually in hand with high effectiveness of labour markets. The effective labour markets should not only lead to traditionally understood low level of unemployment, but they should especially support the speed of reallocation of human capital (Agénor and Canuto, 2015, pp. 641-660) and form support to high level of employment. They should also create incentives for human capital quality improvement (Balcerzak, 2016a) and diminish the risk of forming structural unemployment that is especially socially expensive in the reality of quick technological changes (McKinsey Global Institute, 2002).

\section{Methodology of TOPSIS Analysis}

Technique for Order Preference by Similarity to Ideal Solution (TOPSIS) is a tool often applied in current economic research (Hwang and Yoon, 1981; Yoon and Hwang, 1995). This method is usually used for solving a multiple criteria decision making problems (MADM) and multiple criteria decision analysis (MCDA). TOPSIS is the method for ordering alternatives by similarity to an ideal solution. However, in the article the TOPSIS method is used for description and evaluation of economic objects under consideration, not as it is in the case of MADM for the procedure of choosing the best alternative.

The evaluation of the objects in terms of economic phenomena that have multidimensional character is always based on the set of detailed economic attributes (variables) (Šimková, 2015; Reiff et al., 2016; Balcerzak, 2016b, 2016c; Łyszczarz, 2016; Małkowska \& Głuszak, 2016). Then, on the basis of the used variables a synthetic index can be calculated, which takes into account the effects of all determinants of economic phenomena. The synthetic index evaluated with the TOPSIS method is defined as the similarity or relative closeness to the positive ideal solution. The application of the index 
allows for a synthetic assessment of the development level of phenomenon for every objects. Thus, the usage of TOPSIS method for economic research allows to assess and compare the current situation of the objects.

In the article the modified TOPSIS method is proposed. That method can be applied when there is a possibility to extract complex economic aspects which refer to a specific feature of the object within the researched problem. In that case it is possible to evaluate the objects at two analytic levels: first in terms of distinct chosen aspects by means of synthetic sub-indexes, and then to make the overall evaluation of the objects by means of synthetic index in terms of development of the phenomenon under consideration (Balcerzak and Pietrzak, 2016c).

The procedure of evaluating similarity to the positive ideal solution with modified TOPSIS method starts with the selection of set of object $O_{\mathrm{i}}$ and the economic phenomena under consideration. Then, the subsets of aspects $\left(Y_{1}, Y_{2}, \ldots, Y_{1}\right)$ for the economic phenomena and the set of attributes $X_{1}^{s}, X_{2}^{s}, \ldots, X_{k}^{s}$ for every aspect $Y_{\mathrm{s}}$ should be specified.

In the case of every multiple criteria decision analysis the character of attributes $X_{j}^{s}$ must be classified. As a result, the potential diagnostic variables must be categorized as benefit variables or negative variables. In the case of benefit variables $X_{j}^{s}$ for every two values $x_{i, j}^{s}, x_{k, j}^{s}$ that refer to objects $O_{\mathrm{i}}, O_{\mathrm{k}}$, the relation $x_{i, j}^{s}>x_{k, j}^{s} \rightarrow O_{i} \succ O_{k}$ is fulfilled, where $\succ$ means that object $O_{\mathrm{i}}$ is preferred to $O_{\mathrm{k}}$. In that case a maximum value of variable is preferred. In the case of negative variable $X_{j}^{s}$ for every two values $x_{i, j}^{s}, x_{k, j}^{s}$ that refer to objects $O_{i}, O_{k}$ the relation $x_{i, j}^{s}<x_{k, j}^{s} \rightarrow O_{i} \prec O_{k}$ is fulfilled, where $\prec$ means that object $O_{k}$ is preferred to object $O_{i}$. In that case minimum value of variable is preferred.

In the next step, the specification for every aspect $Y_{\mathrm{s}}$ of decision matrix $Z_{\mathrm{s}}$ should be proposed and the set of variables $X_{j}^{s}$ for every aspect $Y_{\mathrm{s}}$ must be normalised.

During multiple criteria decision analysis in some cases the variables can have different importance in the process of forming analysed multivariate phenomenon. In that situation set of weights $w_{j}^{s}$ for each variable $X_{j}^{s}$ should be specified. Then, normalized variables $X_{j}^{s}$ can be multiplied by weights $w_{j}^{s}$. For every aspect $Y_{s}$ the sum of weights $w_{j}^{s}$ should be equal to 1 .

Next, in the case of every aspect $Y_{s}$ specification for variables $X_{j}^{s}$ the positive ideal solution $I_{s, j}^{P}$ and negative ideal solution $I_{s, j}^{N}$ is done and in the case of every distinct aspect $Y_{\mathrm{s}}$ separation measures $D_{s, i}^{P}$ from the positive ideal solution and $D_{s, i}^{N}$ from negative ideal solution for every object $O_{\mathrm{i}}$ are calculated.

The value of synthetic sub-index $R_{i}^{s}$ that describes every chosen aspect $Y_{\mathrm{s}}$ for every $O_{\mathrm{i}}$ is obtained by combining the proximity to the positive ideal solution and the remoteness from the negative ideal solution, which can be described with the equation (1).

$$
R_{i}^{s}=\frac{D_{s, i}^{N}}{D_{s, i}^{P}+D_{s, i}^{N}}
$$

Relative closeness to the positive ideal solution is a normalized measure usually on scale of $0-1$. With the higher values of the sub-index the higher level of development of the aspect $Y_{\mathrm{s}}$ is received.

Finally, the value of synthetic index $R_{\mathrm{i}}$ is calculated as the weighted arithmetic mean described with the equation (2). 


$$
R_{i}=\sum_{s=1}^{l} w_{s} R_{i}^{s}
$$

where $w_{\mathrm{s}}$ means weights for every aspect $Y_{\mathrm{s}}$ and the sum of weights equals to 1 .

The value of synthetic index $R_{\mathrm{i}}$ describes the level of development of economic phenomena under consideration and the index is also on the scale of $0-1$. High value of index $R_{\mathrm{i}}$ suggests high level of development of economic phenomena for chosen object $O_{\mathrm{i}}$. The application of modified TOPSIS method gives the possibility to order the objects, but it also enables to divide the objects on subsets (classes). For example the method of natural breaks (Jenks method) can be applied for this purpose.

The idea of natural breaks method consists of minimization of variance for objects from the chosen subsets and maximization of variance between the subsets (Jenks, 1967). The division of object into subsets gives the possibility for obtaining relatively homogeneous classes of objects in terms of the level of development of the analyzed phenomenon. As a result, the description of the groups of objects greatly simplifies the interpretation of the results.

\section{The Empirical Analysis in the EU in the years 2000-2013}

In accordance with the aim of the article, the TOPSIS method was applied to evaluation of quality of institutions influencing the ability of the EU member states to utilize potential of the global knowledge-based economy in the years 2000-2013.

The object of the research $O_{\mathrm{i}}$ is a country of the EU. The quality of institutional system for the global knowledge based-economy in the case of the EU countries is economic phenomenon under consideration. The $24 \mathrm{EU}$ countries were included in the research, 14 countries that joined the EU before 2004, and 10 countries that were admitted after 2004 . Luxemburg, Malta, Cyprus and Croatia were excluded from the research. The first three countries were eliminated due to the lack of data for all the period of the planned research. Croatia was not included as it joined the EU only in 2013. The synthetic sub-indexes $R_{i}^{s}$ and synthetic index $R_{\mathrm{i}}$ were calculated for the year 2000, 2006 and 2013.

The period of the research was chosen due to significant socio-political changes that were influencing institutional order in Europe. The first year of the analysis can be considered as a time where most of Central European countries intensified their efforts in reforming their institutional systems for EU accession. The year 2000 presents the initial situation of these countries in the field of quality of their institutions before the years of most intensive reforms necessary for accession to the EU. Comparing that year with 2006 gives the possibility to observe the most important influence of European integration, necessary reforms and social changes in the pre-accession time. The last year of the analysis 2013 gives the possibility to observe the influence of almost ten years of membership on quality of their institutions. It must be remembered that in the case of Bulgaria and Romania that joined EU in 2007 that period was shorter.

The quality of institutional systems is a multivariate and often qualitative economic phenomenon. Based on the theoretical framework discussed in the second section, a vector of potential variables (attributes) divided into four institutional aspects was selected. The first aspect $Y_{1}$ refers to formal regulations influencing entrepreneurship. The second aspect $Y_{2}$ concentrates on effectiveness of juridical system in keeping low level of transaction costs and supporting effectiveness of market mechanism. The third aspect $Y_{3}$ is devoted to the competitive pressure and effectiveness of labour markets. The last one, $Y_{4}$, refers to financial markets institutions as a stimulator of development of enterprises with high growth potential. 
As the research is deeply rooted in the transaction cost theory, many other significant factors from the perspective of the knowledge-based economy, such as the quality of human capital or the effectiveness of national innovation systems were deliberately not included in the research (see Balcerzak and Pietrzak, 2016c; Balcerzak, 2009a, 2015a).

For every aspect, a subset of variables $X_{j}^{s}$ was chosen. All the attributes are presented in Table 1. The set of preliminary variables and the detailed description of information value criteria applied for selection of the final diagnostic variables, which are presented in Table 1, is given by Balcerzak and Pietrzak (2016c). All the data was obtained from Fraser Institute database that is created for the Economic Freedom of the World Reports (see: http://www.freetheworld.com/reports.html). All the attributes are benefit variables and describe different institutional factors on scale of 0-10.

In the preliminary stage the variables $X_{j}^{s}$ were normalized basing on the classic normalization procedure in accordance with equation 3 .

$$
z_{i, j}^{s}=\frac{x_{i, j}^{s}-\bar{x}_{j}^{s}}{d_{j}^{s}},
$$

where: $z_{i, j}^{s}$ - normalized value of $j$ variable $X_{j}^{s}$ for $\underline{\mathrm{i}}$ object for aspect $Y_{\mathrm{s}}, \bar{x}_{j}^{s}$ - arithmetic mean of variable $X_{j}^{s}, d_{j}^{s}$ - standard deviation of variable $X_{j}^{s}$.

Table 1. The vector of attributes used for TOPSIS method

\begin{tabular}{l}
\hline \multicolumn{1}{c}{$Y_{1}-$ formal regulations influencing entrepreneurship } \\
\hline$X_{1}^{1}-$ Administrative requirements for entrepreneurs \\
\hline$X_{2}^{1}-$ Bureaucracy costs for entrepreneurs \\
\hline$X_{3}^{1}-$ The cost of starting business \\
\hline$X_{4}^{1}-$ Extra payments/bribes/favoritism \\
\hline$Y_{2}-$ effectiveness of juridical system in keeping low level of transaction costs \\
$\quad$ and supporting effectiveness of market mechanism \\
\hline$X_{1}^{2}-$ Judicial independence \\
\hline$X_{2}^{2}-$ Impartial courts \\
\hline$X_{3}^{2}-$ Protection of property rights \\
\hline$X_{4}^{2}-$ Integrity of the legal system \\
\hline$Y_{3}-$ competitive pressure and effectiveness of labour markets \\
\hline$X_{1}^{3}-$ Standard deviation of tariff rates \\
\hline$X_{2}^{3}-$ Non-tariff trade barriers \\
\hline$X_{3}^{3}-$ Compliance costs of importing and exporting \\
\hline$X_{4}^{3}-$ Regulatory trade barriers \\
\hline$X_{5}^{3}-$ Foreign ownership/investment restrictions \\
\hline$X_{6}^{3}-$ Capital controls \\
\hline$X_{7}^{3}-$ Controls of the movement of capital and people \\
\hline$X_{8}^{3}-$ Hiring regulations and minimum wage \\
\hline
\end{tabular}


$X_{9}^{3}-$ Hiring and firing regulations

$X_{10}^{3}$ - Centralized collective bargaining

$Y_{4}$ - financial markets institutions as a stimulator of development of enterprises with high growth potential

$X_{1}^{4}-$ Ownership of banks

$X_{2}^{4}-$ Private sector credit

Source: own collection.

In the research an assumption was made that for every aspect $Y_{\mathrm{s}}$ all the weights are equal. As a result the operation of multiplying of normalized variables by weights was not necessary. For every separate institutional aspect $Y_{\mathrm{s}}$ the positive ideal solution $I_{s, j}^{P}$, based on the maximum values, and the negative ideal solution $I_{s, j}^{N}$, based on the minimum values were specified. For the specification of the ideal solutions the maximum and minimum values for the years 2000, 2006 and 2013 were found. This approach gave the possibility of dynamic analysis and comparing the values of synthetic index $R_{\mathrm{i}}$ in the year 2000 with its values in the year 2006 and 2013. As a result, the dynamic analysis of the relative quality of institutions for global knowledge based-economy could be made.

Next, the separation measures $D_{s, i}^{P}$ from the positive ideal solution and $D_{s, i}^{N}$ from negative ideal solution based on the Euclidean distance were estimated. For every aspect $Y_{\mathrm{s}}$ and every object $O_{\mathrm{i}}$ (country) similarity to the positive ideal solution $R_{i}^{s}$ was calculated.

Finally, for every country the values of synthetic index $R_{\mathrm{i}}$ for overall quality of institutional systems was estimated. As it was mentioned above, the values of synthetic index $R_{\mathrm{i}}$ were specified with the assumption that all the weights in the equation 2 are equal. This assumption was taken, as the authors wanted to obtained methodological comparability of this study to the previous work (Balcerzak and Pietrzak, 2016; Balcerzak, 2015). The values of the index gave the possibility to rank the countries for the years 2000, 2006 and 2013. However, in the case of the future research the synthetic measure of institutional quality could be specified with the weighted arithmetic mean, where the weights should be specified arbitrary based on the economic theory and empirical experiences of the countries. That approach was proposed by Żelazny and Pietrucha (2017).

Next, basing on the method of natural breaks the countries were divided into 3 subsets. The subsets were grouping countries with very high, average and low level of the measure of quality of institutions. The final ratings of the countries and obtained subsets are presented in Table 2 and Figure 1. Due to the different distribution of the measure of synthetic index for every year, the subsets formed based on the natural breaks method for next years have different number of countries.

Finally, for every group in the years 2000-2013 an average value of the index of quality of institutions was calculated. In the whole analytical period the changes of the composition of the groups relate to single countries. Thus, the obtained average measures can be compared over the years. The results are presented in Table 3.

Based on the results given in Table 3 it can be seen that in the case of the first class of countries characterised with highest quality of institutions and in the second class the average values of the measure decreased. The increase of the average value of the measure was reached by the third class, grouping the countries with the lowest quality of institutions. It can be the result of relatively deep reforms leading to adjustment of institutions to the requirements of knowledge-based economy. 

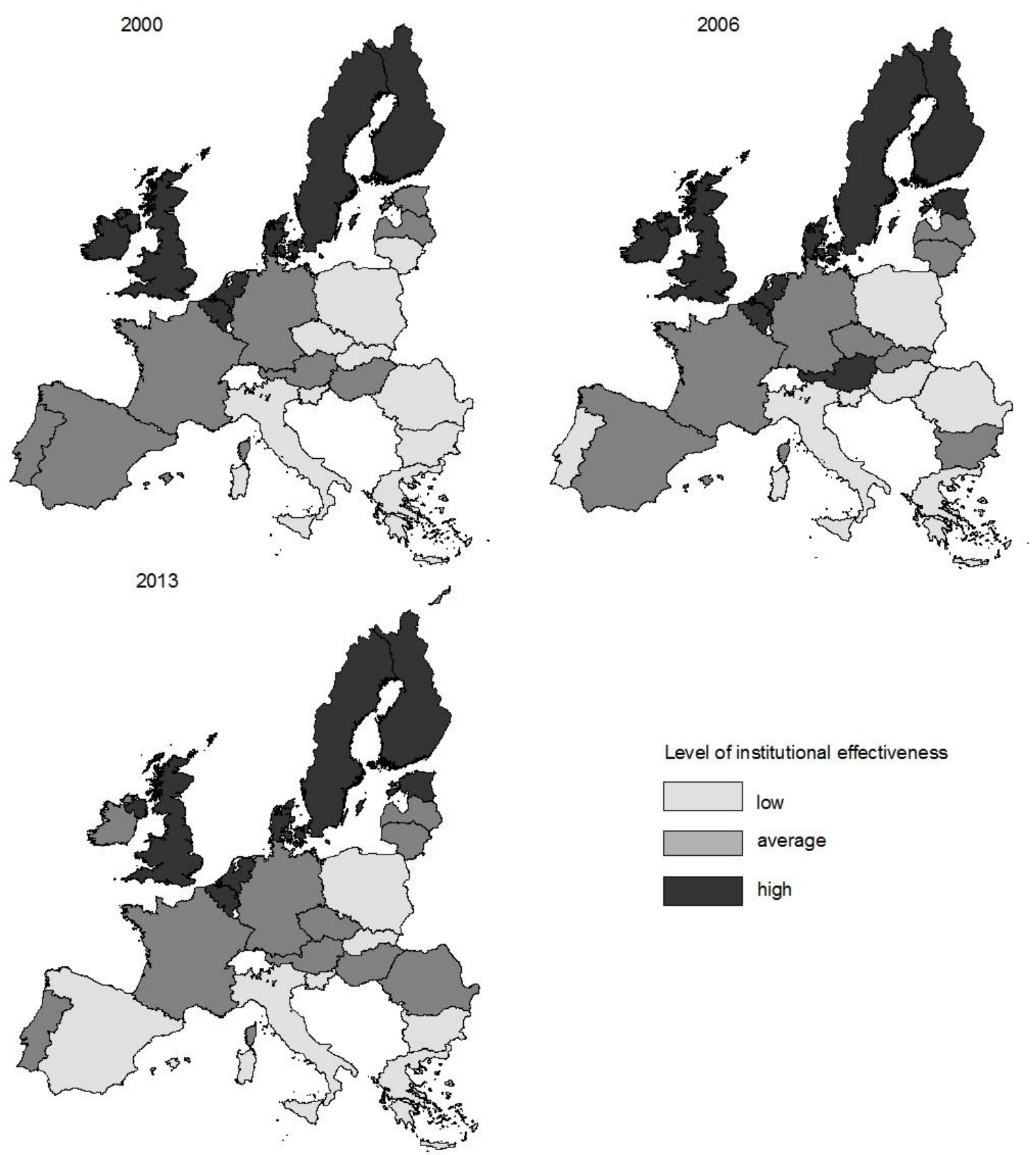

Figure 1. Diversity of EU member states in terms of index of quality of institutions for the global knowledge-based economy

Source: own estimation based on data from Fraser Institute base. 
Table 2. The rating and subsets of EU member countries

\begin{tabular}{|c|c|c|c|c|c|c|c|c|}
\hline \multicolumn{3}{|c|}{2000} & \multicolumn{3}{|c|}{2006} & \multicolumn{3}{|c|}{2013} \\
\hline Country & TOPSIS & Class & Country & TOPSIS & Class & Country & TOPSIS & Class \\
\hline Netherlands & 0,814 & 1 & Denmark & 0,798 & 1 & Denmark & 0,764 & 1 \\
\hline United Kingdom & 0,803 & 1 & Finland & 0,738 & 1 & Finland & 0,751 & 1 \\
\hline Denmark & 0,791 & 1 & Netherlands & 0,736 & 1 & Netherlands & 0,707 & 1 \\
\hline Finland & 0,775 & 1 & Sweden & 0,711 & 1 & Estonia & 0,704 & 1 \\
\hline Ireland & 0,759 & 1 & Ireland & 0,703 & 1 & Sweden & 0,702 & 1 \\
\hline Sweden & 0,719 & 1 & United Kingdom & 0,697 & 1 & United Kingdom & 0,669 & 1 \\
\hline Belgium & 0,709 & 1 & Estonia & 0,695 & 1 & Belgium & 0,660 & 1 \\
\hline Austria & 0,671 & 2 & Austria & 0,692 & 1 & Ireland & 0,636 & 2 \\
\hline Germany & 0,655 & 2 & Belgium & 0,647 & 1 & Austria & 0,622 & 2 \\
\hline Estonia & 0,637 & 2 & France & 0,608 & 2 & France & 0,617 & 2 \\
\hline France & 0,627 & 2 & Latvia & 0,595 & 2 & Germany & 0,589 & 2 \\
\hline Spain & 0,597 & 2 & Germany & 0,570 & 2 & Lithuania & 0,559 & 2 \\
\hline Portugal & 0,539 & 2 & Lithuania & 0,554 & 2 & Latvia & 0,554 & 2 \\
\hline Hungary & 0,531 & 2 & Spain & 0,552 & 2 & Romania & 0,552 & 2 \\
\hline Latvia & 0,522 & 2 & Slovak Rep & 0,536 & 2 & Portugal & 0,551 & 2 \\
\hline Slovenia & 0,484 & 3 & Bulgaria & 0,513 & 2 & Czech Rep. & 0,544 & 2 \\
\hline Italy & 0,482 & 3 & Czech Rep. & 0,507 & 2 & Hungary & 0,529 & 2 \\
\hline Czech Rep. & 0,468 & 3 & Portugal & 0,484 & 3 & Italy & 0,509 & 3 \\
\hline Poland & 0,427 & 3 & Slovenia & 0,483 & 3 & Greece & 0,506 & 3 \\
\hline Lithuania & 0,419 & 3 & Hungary & 0,470 & 3 & Spain & 0,504 & 3 \\
\hline Bulgaria & 0,416 & 3 & Italy & 0,446 & 3 & Slovak Rep & 0,467 & 3 \\
\hline Slovak Rep & 0,410 & 3 & Romania & 0,406 & 3 & Bulgaria & 0,466 & 3 \\
\hline Greece & 0,384 & 3 & Poland & 0,403 & 3 & Poland & 0,417 & 3 \\
\hline Romania & 0,277 & 3 & Greece & 0,393 & 3 & Slovenia & 0,306 & 3 \\
\hline
\end{tabular}

Source: own estimation based on data from Fraser Institute base.

Table 3. The average value of index of quality of institutions for three groups in the years 2000-2013

\begin{tabular}{cccc}
\hline \multirow{2}{*}{ Class } & \multicolumn{3}{c}{ Year } \\
\cline { 2 - 4 } & 2000 & 2006 & 2013 \\
\hline Class 1 & 0,767 & 0,713 & 0,708 \\
\hline Class 2 & 0,597 & 0,554 & 0,575 \\
\hline Class 3 & 0,419 & 0,441 & 0,454 \\
\hline
\end{tabular}

Source: own estimation based on data from Fraser Institute base.

The result presented in Figure 1, Table 2 and Table 3 confirm relatively high stability of obtained indicators, which is consistent with institutional economics theory and experiences of institutional transformation in Central European countries in the end of XX century. Changing quality of institutions, even in the case of formal regulations, is usually a long term process. As a result, in relatively developed and stable economies rapid significant 
changes in that sphere rather should not be expected. If they are recorded, they are usually a result of deep crises such as global financial crisis or significant economic problems in a given country (see: Balcerzak and Pietrzak, 2016c).

Returning to the detailed ratings of countries presented in Table 2 and Figure 1 in the first class with the highest level of institutional quality in the whole period one could find Netherlands, United Kingdom, Denmark, Finland, Sweden and Belgium. In the context of the main aim of the research very good results of Estonia should be notices. In the year 2006 Estonia joined the first subset of the countries and in the year 2013 was classified at fourth position in the ranking, higher than Sweden and United Kingdom (Figure 1 and Table 2). Thus, it can be said that in the last year of the research Estonia was characterized with similar quality of institutions for knowledge-based economy to the most developed EU countries. In that context institutional economist often point out Estonia as an example of the importance of informal institutional long-term factors in forming current formal reforms. As Estonia has close historical and cultural relations with Finland, from the beginning of its transformation from communism to market economy, Estonia benefited from institutional spillover effects from Finland and introduced reforms modelled with the Finnish good practice.

In the second subset in the whole period with the exception of Greece and Italy one can find most of the old member states. However, in the year 2006 and 2013 Latvia, Lithuania and Czech Republic were also rated in this group (Figure 1 and Table 2).

The last class with low level of quality of institutions for knowledge-based economy in the whole period was dominated by such new member states as Slovenia, Poland and southern European countries such as Italy and Greece (Figure 1 and Table 2). Basing on the example of Southern Europe the research proves that low quality of institutional system for the global knowledge-based economy goes in hand with general ineffective macroeconomic governance. All Southern European countries had suffered serious financial destabilization during the last financial crisis, which is still influencing the level of global debt of the European economy. However, special attention should be paid to Greece. In the first year of the research, it was classified as the one before the last in the rating. Additionally to the low level of the index in 2000, in the year 2006 it could be found on the last position in the rating. In the years 2006-2013 the country implemented some reforms and in the last year of the research it was classified on the 19 position in the rating. The example of Greece with its very low quality of institutional system shows that ineffectiveness in that field goes in hand with the overall bad macroeconomic management, as most of the reforms implemented in the second sub-period were the result of the pressure by the European Union countries and the risk of bankruptcy of the country. Apart from the inefficiencies of transformation in some post-transformation countries in the 90's of the 20th century, the example of Greece is also often given as a proof for great importance of institutional factors in forming a country's macroeconomic stability. In this context institutional economists often argue that concentrating only on fulfilling some formal nominal criteria such as convergence Maastricht criteria or the first Washington consensus criteria and underestimation of institutional factors can lead only to temporary improvement of perspectives for growth of a country (see: Rodrik, 2006).

In the context of the main aim of the paper Figure 2 presents the average values of synthetic measure obtained by old member states and Central European countries that joined the EU after 2004. The figure confirms a noticeable distance between two groups of counters. However, it can be also seen that the speed of reforms that improve quality of institutions conducted by new member states during the pre-accession period and in the first years of membership was especially high. It stabilised in the second sub-period. 


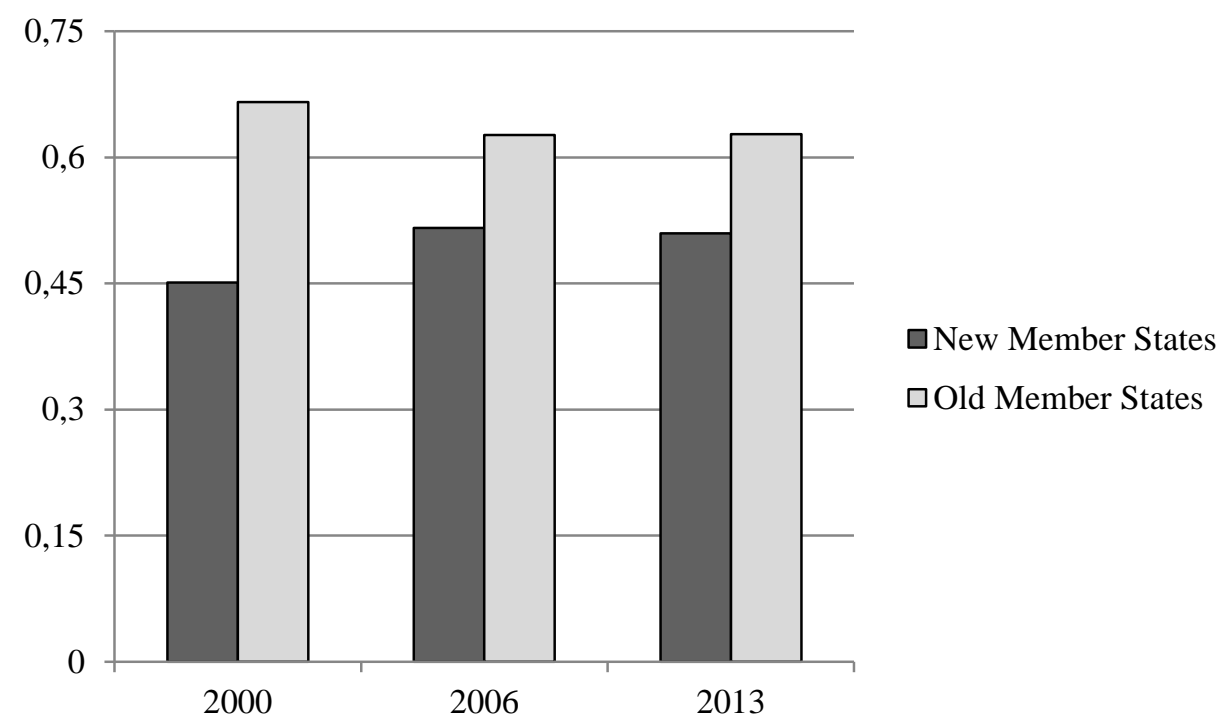

Figure 2. The average values of synthetic measure obtained by new and old member states Source: own estimation based on data from Fraser Institute base.

Figure 3 presents the average values of synthetic measure obtained by new member states, where the average values were calculated separately for Baltic Countries, Visegrad group and Slovenia, Bulgaria and Romania. As a benchmark an average value of the indicator for old member states is also presented here. The figure shows two important changes - the biggest improvement of relative situation in Romania and Bulgaria and noticeable improvement in Baltic countries.

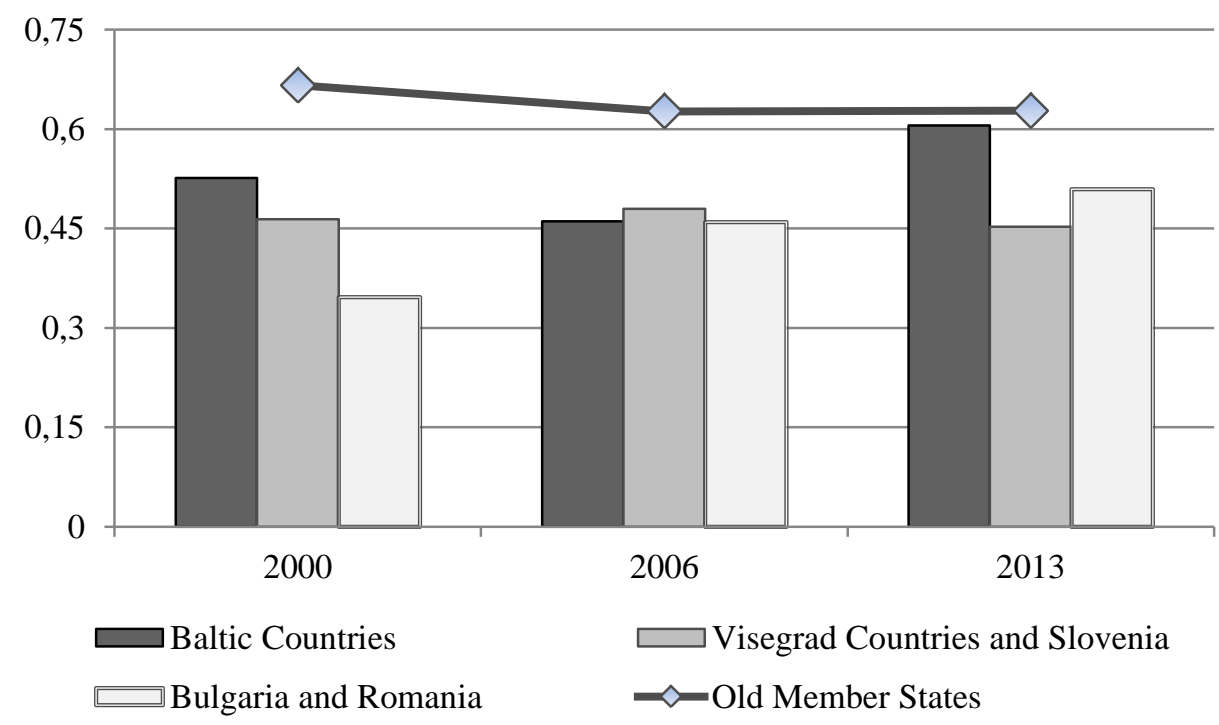

Figure 3. The average values of synthetic measure obtained by new member states Source: own estimation based on data from Fraser Institute base.

It is worth to remember that Romania and Bulgaria were the two countries that joined the EU in 2007. In the first year of the research Romania was characterised with the lowest level of the indicator and Bulgaria was classified at 21 position in the rating. In the year 2006 both Romania and Bulgaria recorded increase of the value of the indicator by 46 and $23 \%$ 
respectively. In the years 2006-2013 in the case of Romania the value of the indicator additionally increased by $36 \%$, as a result in the year 2013 it was higher than in 2000 by $99 \%$. In the case of Bulgaria in the second sub-period the value of the measure decreased by $9 \%$, which was mainly the result of implementing some restrictions in the sphere of investments and capital control after global financial crisis.

The improved situation of Romania could be simply explained as an effects of low statistical base. However, the positive changes in Baltic countries, especially in the case of Estonia show that also the countries with relatively high quality of institutions can still implement reforms leading to noticeable improvements of their relative situation. As a result, as it has been already stressed, in the last year of the research Estonia was classified among the leaders and Latvia and Lithuania recorded the value of the indicator close to Germany. These examples confirm the role of policy factors and long term institutional factors that can affect the abilities of countries to adjust to requirements of global knowledge-based economy (see also: Pietrzak and Balcerzak, 2016a).

In the case of Visegrad group the positive direction of changes can be seen in the case of Czech Republic and Slovak Republic in the first sub-period. In this last country the positive tendency was reversed after global financial crisis.

Recapitulating, Romania, Baltic countries and Czech Republic are the examples of Central European economies that during the period of a few years of EU integration managed to improve noticeably their relative positions. Among the new member states Estonia can be described as an example of especially significant improvement of quality of institutions for the global knowledge-based economy. At the same time, Slovenia is an example of a country that lacks reforms and loses its potential in relation to the rest of the region, as in 2013 the country was degraded to the lowest position in the ranking.

\section{Conclusions}

The main aim of the research was the evaluation of the progress of new member states of the EU in term of their improvements in forming quality of institutional systems for the knowledge-based economy. Based on the results, it is not possible to falsify the main research thesis. These countries have gained many direct advantages of European integration such as increase of their trade, improvement of their international competitiveness and GDP growth. At the same time, the integration was the source of many indirect benefits. Undoubtedly, in the case of Central European countries joining the EU has positively influenced their institutional reforms in the context of the global knowledge-based economy. This can be seen in the changes of synthetic index for some of the countries in the region. Naturally, the scale of the benefits depended on the countries' effort toward significant reforms influencing the level of transaction costs in the economy. The Baltic Countries, Romania and Czech Republic can be treated as positive examples in that field. In the group of Central European countries Slovenia can be pointed as a negative example in the context of the reforms influencing transaction costs in the economy.

With regard to the additional aim of the article, it can be seen that Scandinavian countries, Netherlands, Belgium and United Kingdom are characterized by the highest values of the synthetic measure, which proves their leading role in the field of quality of institutional systems for the knowledge-based economy.

In the broader context of effectiveness of macroeconomic policy, it is worth to notice that high quality of institutions goes in hand with prudent public finance management. In spite of the fact that Scandinavian countries are traditionally considered as examples of welfare states economies, in the whole analyzed period they can be characterized by much better financial standing than the rest of the old member states. This factor can suggest a positive 
relation between institutional effectives for the global knowledge-based economy and effectiveness of public financial management.

\section{References}

Balcerzak, A. P. (2009a), Effectiveness of the Institutional System Related to the Potential of the Knowledge Based Economy, Ekonomista, 6, pp. 711-739.

Balcerzak, A. P. (2015a), Wielowymiarowa analiza efektywności instytucjonalnej w krajach Europy Środkowowschodniej w relacji do standardów OECD, Optimum. Studia Ekonomiczne, 1(73), pp. 51-63.

Balcerzak, A. P. (2015b), Europe 2020 Strategy and Structural Diversity Between Old and New Member States. Application of Zero-unitarizatin Method for Dynamic Analysis in the Years 2004-2013, Economics \& Sociology, 8(2), pp. 190-210, DOI: dx.doi.org/10.14254/2071-789X.2015/8-2/14.

Balcerzak, A. P. (2016a), Multiple-criteria Evaluation of Quality of Human Capital in the European Union Countries, Economics \& Sociology, 9(2), pp. 11-25, DOI: 10.14254/2071-789X.2016/9-2/1.

Balcerzak, A. P. (2016b), Technological Potential of European Economy. Proposition of Measurement with Application of Multiple Criteria Decision Analysis, Montenegrin Journal of Economics, 12(3), pp. 7-17, DOI: 10.14254/1800-5845.2016/12-3/1.

Balcerzak, A. P. (2016c), Fiscal Burden in the European Union Countries, Economics Annals XXI, 161(9-10), pp. 4-6, DOI: https://doi.org/10.21003/ea.V161-01.

Balcerzak, A. P. \& Pietrzak, M. B. (2016a), Structural Equation Modeling in Evaluation of Technological Potential of European Union Countries in the Years 2008-2012, In: M. Papież \& S. Śmiech (Eds.), The 10th Professor Aleksander Zelias International Conference on Modelling and Forecasting of Socio-Economic Phenomena. Conference Proceedings, Cracow: Foundation of the Cracow University of Economics, pp. 9-18, Retrieved from: http://econpapers.repec.org/bookchap/pesecchap/10.htm.

Balcerzak, A. P. \& Pietrzak, M. B. (2016b), Human Development and Quality of Institutions in Highly Developed Countries, In: M. H. Bilgin, H. Danis, E. Demir, and U. Can (Eds.), Financial Environment and Business Development. Proceedings of the 16th Eurasia Business and Economics Society, Springer International Publishing, pp. 231-241.

Balcerzak, A. P. \& Pietrzak, M. B. (2016c), Efektywność instytucjonalna krajów Unii Europejskiej, Ekonomista, 3, pp. 312-337.

Balcerzak, A. P. \& Pietrzak, M. B. (2016d), Quality of Human Capital in European Union in the Years 2004-2013. Application of Structural Equation Modeling, In: Proceedings of the International Scientific Conference Quantitative Methods in Economics Multiple Criteria Decision Making XVIII, Vratna: Letra Interactive, pp. 7-12.

Bassanini, A., Scarpetta, S., \& Visco, I. (2000), Knowledge, Technology and Economic Growth: Recent Evidence from OECD Countries, OECD Economics Department Working Papers, 259, ECO/WKP(2000)32.

Bassanini, A., Scarpetta, S., \& Hemmings, P. (2001), Economic Growth: The Role of Policies and Institutions. Panel Data Evidence From OECD Countries, OECD Economics Department Working Papers, 283, ECO/WKP(2001)9.

Buchanan, J., \& Chai, D. H., \& Deakin S. (2014), Empirical analysis of legal institutions and institutional change: multiple-methods approaches and their application to corporate governance research, Journal of Institutional Economics, 10(1), pp. 1-20.

Denis, C., Mc Morrow, K., Röger, W., \& Veugelers, R. (2005), The Lisbon Strategy and the EU's structural productivity problem, European Economy, European Commission Directorate-General for Economic and Financial Affairs, Economic Papers, 221. 
International Bank for Reconstruction and Development/The World Bank (2013), Doing Business 2014: Understanding Regulations for Small and Medium-Size Enterprises, Washington: World Bank Publications.

Fałdziński, M., Balcerzak, A. P., Meluzín, T., Pietrzak, M. B., \& Zinecker, M. (2016), Cointegration of Interdependencies Among Capital Markets of Chosen Visegrad Countries and Germany, In: A. Kocourek, M. Vavrousek (Eds.), $34^{\text {th }}$ International Conference Mathematical Methods in Economics MME 2016 Conference Proceedings, Liberec: Technical University of Liberec, pp. 189-194.

Felipe, M. \& Oto, P. (2015), Does the EU Funding Increase Competitiveness of Firms by Supporting Organisational Changes? Journal of Competitiveness, 7(2), pp. 23-37, DOI: 10.7441/joc.2015.02.02.

Gust, M., \& Marquez, J. (2000), Productivity Developments Abroad, Federal Reserve Bulletin.

Gwartney, J., Lawson, R., \& Hall, J. (2015), Economic Freedom of the World: 2015 Annual Report, Fraser Institute.

Hwang, C. L., \& Yoon, K. (1981), Multiple Attribute Decision Making: Methods and Applications, Heidelberg: Springer, http://dx.doi.org/10.1007/978-3-642-48318-9.

Jantoń-Drozdowska, E., \& Majewska, M. (2016), Investment Attractiveness of Central and Eastern European Countries in the Light of New Locational Advantages Development, Equilibrium. Quarterly Journal of Economics and Economic Policy, 11(1), pp. 97-119, DOI: http://dx.doi.org/10.12775/ EQUIL.2016.005.

Jenks, G. F. (1967), The Data Model Concept in Statistical Mapping, International Yearbook of Cartography, 7.

Kondratiuk-Nierodzińska, M. (2016), New Knowledge Generation Capabilities and Economic Performance of Polish Regions, Equilibrium. Quarterly Journal of Economics and Economic Policy, 11(3), pp. 451-471, DOI: http://dx.doi.org/10.12775/EQUIL.2016.021.

Kordalska, A., \& Olczyk, M. (2016), Global Competitiveness and Economic Growth: A OneWay or Two-Way Relationship?. Equilibrium. Quarterly Journal of Economics and Economic Policy, 11(1), pp. 121-142, DOI: http://dx.doi.org/10.12775/ EQUIL.2016.006.

Kowalska, I. (2016), Sources of Financing Knowledge-Based Economy: the Case of Formal, Non-Formal and Informal Education in Poland, Oeconomia Copernicana, 7(1), pp. 7590, DOI: http://dx.doi.org/10.12775/OeC.2016.006.

Lizińska, W., Marks-Bielska, R., Babuchowska, K. \& Wojarska, M. (2016), Institutional Efficiency of Local Government in Issuing Administrative Decisions, Exemplified by the Performance of the Local Government Appeal Board in Olsztyn, Oeconomia Copernicana, 7(2), pp. 285-296, DOI: http://dx.doi.org/10.12775/OeC.2016.017

Łyszczarz, B. (2016), Public-private Mix and Performance of Health Care Systems in CEE and CIS Countries, Oeconomia Copernicana, 7(2), pp. 169-185, DOI: http://dx.doi.org/10. 12775/OeC.2016.011.

Małkowska, A., \& Głuszak, M. (2016), Pro-investment Local Policies in the Area of Real Estate Economics - Similarities and Differences in the Strategies Used by Communes, Oeconomia Copernicana, 7(2), pp. 269-283, DOI: http://dx.doi.org/10.12775/OeC.2016.016.

McKinsey Global Institute (2002), How IT Enables Productivity Growth. The US Experience Across Three Sectors in the 1990s', McKinsey Global Institute, High Tech Practice, Business Technology Office, San Francisco.

Meluzín, T., \& Zinecker, M. (2016), Trends in IPOs: The Evidence from CEE Capital Markets, Equilibrium. Quarterly Journal of Economics and Economic Policy, 11(2), pp. 327-341, DOI: http://dx.doi.org/10.12775/ EQUIL.2016.015.

Miller, A. T., Kim, A. B., Roberts, J. M., Riley, B., \& Whiting, T. (2016), 2016 Index of Economic Freedom, The Heritage Foundation, The Wall Street Journal. 
North, D. C. (1991), Institutions, Journal of Economic Perspectives, 5(1), pp. 97-112.

North, D. C. (1993), Institutions, Transaction Costs and Productivity in the Long Run, Economic History 9309004, Economics Working Paper Archive at WUSTL.

North, D. C. (1994a), Institutions And Productivity, In: History. Economic History 9411003, EconWPA.

North, D. C. (1994b), Economic Performance through Time, American Economic Review, 84(3), pp. 359-368.

OECD (2001), The New Economy. Beyond the Hype, Paris: OECD.

Pierre-Richard Agénor P.-R. \& Canuto, O. (2015), Middle-income Growth Traps, Research in Economics, 69(4), pp. 641-660.

Pietrzak, M. B., \& Balcerzak, A. P. (2016a), Assessment of Socio-Economic Sustainability in New European Union Members States in the years 2004-2012, In: M. Papież \& S. Śmiech (Eds.), The 10th Professor Aleksander Zelias International Conference on Modelling and Forecasting of Socio-Economic Phenomena. Conference Proceedings, Cracow: Foundation of the Cracow University of Economics, pp. 120-129.

Pietrzak, M. B. \& Balcerzak, A. P (2016b), Quality of Human Capital and Total Factor Productivity in New EU Member States, In: T. Loster \& T. Pavelka (Eds.), The 10th International Days of Statistics and Economics. Conference Proceedings. September 810, 2016, Prague: Libuse Macakova, Melandrium, pp. 1492-1501.

Pohulak-Żołędowska, E. (2016), Innovation in Contemporary Economies, Oeconomia Copernicana, 7(3), pp. 451-466, DOI: http://dx.doi.org/10.12775/OeC.2016.026.

Reiff, M., Surmanová, K., Balcerzak, A. P., \& Pietrzak, M. B. (2016), Multiple Criteria Analysis of European Union Agriculture, Journal of International Studies, 9(3), DOI: 10.14254/2071-8330.2016/9-3/5.

Rodrik, D. (2006), Goodbye Washington Consensus, Hello Washington Confusion? A Review of the World Bank's Economic Growth in the 1990s: Learning from a Decade of Reform, Journal of Economic Literature, 44(4), pp. 973-987, DOI: $10.1257 / 002205106779436251$.

Rodrik, D. (2007), One Economics, Many Recipes: Globalization, Institutions, and Economic Growth, New Jersey-Oxfordshire: Princeton University Press.

Scarpetta, S., \& Tressel, T. (2004), Boosting Productivity via Innovation and Adoption of New Technologies: Any Role for Labor Market Institutions? World Bank Policy Research, Working Paper 3273.

Schwab, K., \& Sala-i-Martín, X. (2015), The Global Competitiveness Report 2015-2016, World Economic Forum.

Šimková, N. (2015), The Hierarchical Clustering of Tax Burden in the EU 27, Journal of Competitiveness, 7(3), pp. 95-109, DOI: http://dx.doi.org/10.7441/joc.2015.03.07.

Williamson, O. E. (1985), The Ecnomic Institututions of Capitalism. Firms, Markets, Relational Contracting, The Free Press, a division of simon \& SchusterInc.

Yoon, K. P., \& Hwang, C. L. (1995), Multiple Attribute Decision Making: An Introduction, Thousand Oaks: CA Sage Pub.

Zinecker, M., Koppitz, D., \& Režňáková, M. (2013), Investigation of Business Angels and Issues with Innovative Entrepreneurship in the Czech Republic, International Journal of Economics and Statistics, 2(1), pp. 37-48.

Zinecker, M. \& Bolf, D. (2015), Venture Capitalists' Investment Selection Criteria in CEE Countries and Russia, Verslas: Teorija ir praktika / Business: Theory and Practice, 16(1), pp. 94-103, DOI: 10.3846/btp.2014.441.

Żelazny, R., \& Pietrucha J. (2017), Measuring Innovation and Institution: the Creative Economy Index, Equilibrium. Quarterly Journal of Economics and Economic Policy, 12(1) (forthcoming). 